Journal of Southeast Asian

\title{
Cambodian American Views of Partnerships in Public Education
}

Peter T. Keo

University of Pennsylvania, petertankeo@gmail.com

Follow this and additional works at: https://docs.lib.purdue.edu/jsaaea

Part of the Teacher Education and Professional Development Commons

\section{Recommended Citation}

Keo, Peter T. (2019) "Cambodian American Views of Partnerships in Public Education," Journal of Southeast Asian American Education and Advancement: Vol. 14 : Iss. 1, Article 1.

DOI: $10.7771 / 2153-8999.1158$

Available at: https://docs.lib.purdue.edu/jsaaea/vol14/iss1/1

This document has been made available through Purdue e-Pubs, a service of the Purdue University Libraries. Please contact epubs@purdue.edu for additional information.

This is an Open Access journal. This means that it uses a funding model that does not charge readers or their institutions for access. Readers may freely read, download, copy, distribute, print, search, or link to the full texts of articles. This journal is covered under the CC BY-NC-ND license. 


\title{
JSAAEA Journal of Southeast Asian American
Education and Advancement
}

Vol. 14 Iss. 1 (2019)

WWW.JSAAEA.org

\section{Cambodian American Views of Partnerships in Public Education}

\author{
Peter. T. Keo \\ University of Pennsylvania
}

\begin{abstract}
This study elicits the views of Cambodian American adults regarding public school partnerships. The central argument is that the paucity of extant literature and research on Southeast Asian American (SEAA) family-school partnerships in public education renders these individuals invisible. Given the fluid and dynamic experiences across and within the SEAA community, there is critical need for empirical research to address issues particular to ethnic groups, because racial categories often conceal disparities behind the numbers. Surveys and semi-structured interviews are utilized to collect data from Cambodian American respondents. Findings suggest the importance of culture and structure in building critical partnerships.
\end{abstract}

Keywords: Race and equity, K-12 Education, Southeast Asian Americans, Cambodian Americans, Family-school partnerships.

\footnotetext{
(C)

SDRERIIGHISRESERNEDR Readers are free to copy, display, and distribute this article, as long as the work is attributed to the author(s) and the Journal of Southeast Asian American Education \& Advancement, it is distributed for non-commercial purposes only, and no alteration or transformation is made in the work. More details of this Creative Commons license are available at http://creativecommons.org/licenses/by-nc-nd/3.0/. All other uses must be approved by the author(s) or JSAAEA . Journal of Southeast Asian American Education \& Advancement, Vol. 14. Iss. 1. (2019) ISSN: 2153-8999
} 


\section{Introduction}

A growing body of scholars and researchers (Aung \& Yu, 2007; Kiang, 2004a; Kiang, 2004b; Ngo \& Lee, 2007; Pho 2007; Thao, 2003; Uy, 2007) has examined critical challenges facing several low-income Southeast Asian American (SEAA) students, particularly in under-resourced American public-school systems. For example, in "Does the System Work for Cambodian American Students?" Khin Mai Aung and Nancy Yu (2007) explore different interconnected factors that impact the educational experiences of Cambodian youth in Lowell, MA. Some factors include the challenges and root causes contributing to the high dropout rate of Cambodian youths, the cultural and linguistic barriers of family members, financial constraints, the cultural differences between family members and school staff, low levels of family educational attainment, the inability of family members to maneuver within the American educational system, and the prevalence of gang life.

Aung and $\mathrm{Yu}$ (2007) examine the educational attainment of individuals who were 18 years and over in Lowell. They find that $55.6 \%$ of Cambodians are without a high school degree, compared to $46.3 \%$ of Hispanics or Latinos (of any race), $42.3 \%$ Non-Hispanic Asians, $22.1 \%$ Non-Hispanic Whites, and $15.9 \%$ of Non-Hispanic Blacks or African Americans. These percentages reflect the entire population of these groups in Lowell. Some researchers argue that educational attainment is a strong predictor of upward mobility (Kao \& Tienda, 1995). Aung and $\mathrm{Yu}$ also note that many Cambodian students "were falling through the cracks of an overcrowded and under-resourced public school system-leading many students to be truant or drop out" ( $p$. 88). They further note that "out-of-school youth were more likely to become involved in the criminal justice system" (p. 89) and that "Cambodian students don't know how to seek assistance from their teachers, don't think the teachers understand them, and sometimes they seek outside help that may not be positive" (p. 102). Citing a personal communication, the authors point out that some youth look to gang members as a surrogate family, largely in response to failures or frustration in dealing with the school system "especially if their parents are not engaged in their education and an older sibling is already involved with a gang-offering the 'instant gratification' of needed support and belonging" (p. 102). Research suggests that family involvement may have positive effects on young people, including improvements in student outcomes for SEAA youth (Pho, 2007; Thao, 2003). This is particularly evident for young individuals at risk of school failure (Nakkula \& Pineda, 2005).

Aung and $\mathrm{Yu}$ also examine the implications of cultural and linguistic barriers among Cambodian family members and children and the impact of those barriers on educational experiences. Cambodian family members, they note, "lack formal education themselves and/or do not understand how to maneuver within the American education system" (Aung \& Yu, 2007, p. 93). Quoting an anonymous youth advocate, the authors state that "some parents themselves never even graduated from middle school, so they don't push their children at all. ... Even though they value education, it's like their dream and reality is a different story" (p. 93). Cambodian family members' inability to maneuver through the school system may in part result from their inexperience not only with the U.S. public educational system, but also school systems in Cambodia.

Pho (2007) examines the interplay between family education and academic performance among SEAA students, specifically how cultural values and family life may influence the academic performance of their children. This research is based on a survey of 102 SEAA high school students and a case study of two Cambodian, two Laotian, and two Vietnamese families, 
from the pool of students surveyed. Findings from the data suggest that "the voices emerging from these short stories and poems were more compelling than any available statistical reports" (2007, p. 71), because the challenges and opportunities individuals face at home and in school are revealed to the researcher.

Regarding the nature of family and school partnerships, Pho purports that the "notion of parental participation in school was very different between parents and teachers. While teachers complained that family members rarely came to school open houses or attended teacher-parent conferences, family members thought they participated sufficiently in their children's school education by reminding their children to do homework and teaching them the value of education" (2007, p. 81). SEAA family members may believe that teaching their children the value of hard work, determination, and a strong work ethic constitutes an involvement in the child's education, without being physically present or active in school-based activities/functions (for similar issues regarding other ethnic minority families, see Lopez, 2001; Silva, 2001). However, Pho acknowledges that the imposed values of family members may have some potential adverse effects, including the forceful nature of family members to dictate what the child should study in college, without the child's consent. It also may include an overprotective parenting style that limits the young person's ability to attend college far away from home, which tends to affect girls more than boys. Pho's study raises important issues regarding the nature of family education and academic performance for SEAA families and students, and how families, students, and teachers can work together. A strong premium is placed on understanding how cultural values and linguistic barriers may impact the learning process.

Other scholars interested in SEAAs address related issues in education. For example, Kiang (2004b) documents a series of K-12 strategies developed within an Asian American (AA) Studies Program at one urban public university. Four issues are addressed: a) the complex demographic realities of AA populations; b) the exclusion of AA Studies content in the K-12 curriculum; c) the limited flow of AAs into the field of education; and d) the confounding impact of high-stakes testing across all these areas. The same article describes six specific interventions by a universitybased AA Studies program, with one focused on "advocacy capacity-building for Asian-American parents and families" (p. 217).

Goodwin (2010) explores the curriculum as colonizer for AAs. Her work is pivotal for this study in that it attempts to explain the negative implications of the standard American K-12 curriculum, which does not account for AA voices. On many levels, it disempowers marginalized ethnic minorities by "colonizing" the minds of AAs, which of course includes SEAA students, as curricular contents reinforce the notion of the "perpetual foreigner." While she discusses learning implications for young people, Goodwin's research makes the case that the American educational system in general, within which the curriculum is embedded, does not necessarily create an environment that invites people of color to have their voices heard. This may explain why some SEAA families may feel disengaged, if not completely disempowered, from reaching out to teachers. It also may prevent families from being more involved in activities led and run by school partners, many of whom represent the interests of middle-class, White Americans. Regarding Asian and Pacific Islanders (APIs), Goodwin mentions that "the curricular silence surrounding them seems designed to reinforce their status as perpetual foreigners. ... Curriculum clearly transmits the message that they hold no membership in the 'American' story" (p. 3122).

Despite a growing body of research on the importance of family-school partnerships (Epstein, 1995, 2001a, 2001b, 2008; Epstein \& Salinas, 2004; Henderson \& Mapp, 2002; Henderson, Mapp, Johnson \& Davies, 2007; Stevenson \& Baker, 1987), existing family-school 
partnerships - in practice and research — can be more effective in supporting Cambodian American families, especially those with limited English proficiency. Given the vast ethnic, cultural, and linguistic differences across the AA community (see CARE, 2010, 2011), it may be useful to strengthen family-school partnerships that speak directly to the needs of Cambodian families. In doing so, this partnership may enable Cambodian families to have a voice at the table, while further enabling families and school partners to address academic and/or behavioral issues that may arise regarding their children. Research on the impact of family-school partnerships indicates positive outcomes on the family and child. Outcomes often include increased family involvement, increased attendance, reading, writing, and math achievement, in addition to improved report card grades and behavior (Epstein, 1995, 2001a, 2001b; Henderson \& Mapp, 2002; Sheldon \& Epstein, 2002).

\section{Purpose of the Study}

The present study elicits the views of seven Cambodian American refugees (see Table 1, for a description of respondents) regarding public school partnerships. I utilize baseline surveys to gather background information on adults, in addition to in-depth, semi-structured interviews which allowed me to answer the main research question: What does family-school partnership mean to Cambodian American families? I rely on purposive sampling to recruit respondents for the study. All respondents live in a major metropolitan city of Texas. The central argument is that the paucity of extant literature and research on SEAA family-school partnerships in public education renders these individuals invisible. Given the fluid and dynamic lived experiences across and within the SEAA community, there is critical need for empirical research that addresses issues particular to ethnic groups. Studies often assume that Cambodian American families already have power and ownership in schools. In this context, the voices of Cambodian American families have not been sufficiently documented. This study aims to provide the temporal and spatial context within which voice and agency can be afforded. This research supports critical race theory's voice-of-color thesis, which holds that because of different histories and experiences with oppression, ethnic minority writers and thinkers may be able to communicate matters that members of the dominant racial group are unlikely to know. Thus, minority status brings with it a presumed competence to speak about issues related to race and equity in public education (Delgado \& Stefancic, 2012).

\section{Method}

\section{Data Source}

Research setting. I select a church as the research setting: The Cambodian Church of Texas was the pseudonym. The church is selected in preference to a Buddhist temple for many reasons. First, though most Cambodian families subscribe to Theravada Buddhism, the church is ideal largely because many Cambodian families congregated on a regular basis (i.e., every Sunday). Conversely, Cambodian Buddhists tend to visit their respective temples irregularly and only during major holidays/celebrations, usually once or twice every few months. The irregularity of attendance is a huge concern for me, specifically in terms of having the time, space, and opportunity to build trust with respondents. Another important reason for selecting this setting is based on accessibility to the family members, some of whom welcomed me into their community. The church also is centrally located in an area that was home to several Cambodian families. That 
they are concentrated in one area suggests that they choose to live within proximity to those sharing similar ethnic, cultural, and linguistic values (Suarez-Orozco \& Suarez-Orozco, 2001; see also Portes \& Rumbaut, 2001).

Data collection. I collect primary data using baseline surveys and semi-structured interviews. Surveys are handed out to 30 people. I spent 12 months building trust with church members, explaining to them the purpose of the study. Only seven people are interviewed in the study though my initial goal was to interview over 20 adults. The low response rate is a huge disappointment despite months of recruitment. Perhaps it speaks to the continued challenges in getting SEAA adults (who themselves are largely refugees) to trust researchers, which is further extrapolated in the section below. The entire interview process lasted roughly 13 months.

Challenges in finding people to participate. Prior to selecting this research setting and participants, I reached out to Asian American non-profit leaders and scholars throughout the United States to determine if they could help identify Cambodian adults for the study. My doctoral advisers at the time did not have access to the community. However, with no success, I decided to turn to my father who introduced me to an informal friend. This friend was the pastor of the church.

As I began data collection, I started to realize that some Cambodian family members were not interested in participating in the study. I ran into challenges despite spending months trying to build trust in a place that was familiar to them. I was especially surprised when families spoke freely and openly during informal discussions at the church but became silent when the time had come to participate. I thought I had chosen a relatively "safe" topic to discuss about which something most - if not all—parents would feel comfortable addressing. I recognize that there may have been factors beyond my control that impacted their decision not to participate. Perhaps more trust-building is required with Cambodian adults still scarred by the genocide and perhaps less willing to share personal information with researchers.

\section{Data Analysis}

Regarding the literature review, I review the work of researchers who conduct qualitative studies on family-school partnerships, family involvement in education, and SEAA issues in education. Sandoval's (2007) unpublished study is particularly helpful in selecting the appropriate qualitative methods to analyze data. Similar to Sandoval's study, I use the constant comparison method (Glaser \& Strauss, 1967). The purpose of constant comparison is to jointly code and analyze data to generate new theories as they emerge. Constant comparison allows researchers to guard against researcher bias when themes emerge organically. Once themes emerge, they are compared across all interviews to check for fit and workability. I continue this process, starting with the first interview and working to the last, going back and forth, until the main themes emerge from the interviews.

Coding. I conduct two rigorous rounds of coding. For round one, NVivo is used to organize information and analyze data. Round one yields 27 codes that are extremely broad. However, a deep(er) analysis of the data is reached in round two. I code using cogent phrases to avoid being overly categorical in round two. The second round helps to avoid clichés and creates detailed codes. NVivo is abandoned for the second round, in part because the license had expired. Instead, 
Word documents are used for coding and analysis. I compare codes from round two with those from round one several times.

External validity. Generalizability is not possible given the size of the study. However, while findings are not generalizable, they have meaning for more than the study participants. Importantly, doctoral students and researchers interested in learning about the views of Cambodian American families, particularly with respect to family-school partnerships and/or family involvement in education may find this research useful. They may refer to this study to better understand whether families view partnerships similarly or differently from other families. They may also seek to better understand how Cambodian Americans view culture, for example, in building effective partnerships with school partners.

Table 1. Description of respondents.

\begin{tabular}{lrrr}
\hline Respondent Name & Respondent Age & Children & Dates Children Attended \\
Steve & Late 50s & Daughter & 12 Schools \\
& & Son & $1989-2002$ \\
& & Son & $1990-2003$ \\
David & Late 50s & Daughter & $1987-2000$ \\
& & Daughter & $1991-2004$ \\
Paula & Late 70s & Daughter & $1996-2009$ \\
Larry & Mid 40s & Daughter & $1980-1993$ \\
& & Step-daughter & $2001-$ Present \\
Sarah & Early 40s & Son & $2008-$ Present \\
& & Daughter & $2001-$ Present \\
Amy & Early 40s & Son & $2008-$ Present \\
& & Daughter & $2000-2013$ \\
Charles & Early 50s & Son & $2002-$ Present \\
& & Son & $1987-2000$ \\
\hline
\end{tabular}

\section{Researcher's Positionality}

I am an American raised proudly by low-income, working-class Cambodian political refugees. (The entire immediate family of both my parents did not survive the genocide.) I was educated in an urban K-12 public school system in the so-called "South" in which the confederate battle flag was waived freely by peers, often without repercussion by (White) teachers. Given my epistemological orientation, I necessarily bring a critical lens of being at once "SEAA" and a "Brown, not Yellow" first-generation, high school graduate who transitioned through the K-12 and higher educational system largely invisible despite my disadvantaged, ethnic minority background. Despite holding a doctorate from an elite Ivy League institution, I am still trying to navigate systems and institutions in higher education, the workforce, and society writ large in which marginalized Asian Americans have been (and to a large extent, continue to be) politically 
and culturally wedged between Whites on one end and Blacks/African Americans on the other (Lee, 2006; Ong, 1999; Wu, 2003).

\section{Findings}

\section{Building Family-School Partnerships through Communication}

Respondents define "communication" in two ways. One way is the sharing of information about the child's progress especially timely information for interventions. The other form of communication is cultural understanding, which is on a more personal level. There are two patterns under this theme. The first pattern, "contacting parents about problems," is about the child's progress. The second pattern, "learning culture between families and teachers," is about cultural understanding. Both patterns are represented further below as Pattern A and Pattern B, respectively.

In terms of building family-school partnerships through communication, all respondents appear to support the notion that communication between teachers and families is important. To respondents, family-school partnerships refer to families and teachers communicating with each other and working together. One way to do that is to share information about how their children are doing at school. In communicating with each other, parents are expected to know what teachers are teaching and support teachers in any way possible.

For example, Steve notes, "Relationship is very important for the parent and the school ... anything the teacher want to know about our children, then we can tell them." Steve also suggests that the place to have this conversation is at school, where parents and teachers can have an open dialogue. He goes on to note, "At school they always have teacher and parents meet ... and that's the partnership ... we can know what the teacher is teaching our children and what we can do to help them." Paula also believes that parents and teachers should communicate at school, because "That's the time when your children are not there. Adults are talking." That appears to suggest that parents and teachers can have more time to discuss issues, both good and bad, without children present. If children are present, Paula may be suggesting that parents and teachers may not speak candidly, and that could be a challenge in itself because it may prevent adults from identifying challenges that may hinder children, at home or at school.

Amy also believes that family-school partnerships mean that parents and teachers talk to each other at school about the progress of their children. Amy notes:

Get involved with your school. Go to PTA meetings. Talk to the counselors. Talk to the teachers ... just get to know the teacher, what they teaching at school, so when they come home, you have an idea of what they're learning at school.

Amy believes that parents ought to talk to teachers directly in order to have a better understanding of what their children are learning. This may have been important, because it better enables her to know, for example, whether or not her children are staying ahead or falling behind academically and/or behaviorally.

David also speaks to the importance of having an open channel of communication between families and teachers. That partnership means that teachers ought to use different ways to share information with him, especially if teachers witness his children struggling at school. He notes, "If my children have a problem at school, I think that is a good communication. Teachers call me, 
they send a letter, they do something to help our children, to let me know as a father, as a parent." However, as a parent, David also speaks to the importance of regularly checking in with his children. Thus, family-school partnerships mean being vigilant and checking in with his children, in addition to speaking with teachers in the event his children confront issues at school. He notes:

As long as I talk to my children, "How is school going and everything," and if they say that everything is okay, and I check the grade point average and the grade each semester ... that is good, then I think the teacher is doing a very good job.

David may use grades and grade point averages as indicators of his children's academic success whether his children are falling behind or advancing in school. If they are lagging academically, then the teacher may have a better understanding of why they are struggling. Thus, family-school partnerships mean that he checks in with teachers to monitor his children's academic progress. David would engage teachers if his children are failing classes to take corrective action.

For Paula, it is important to have an open channel of communication between families and teachers, perhaps given her status as a single mother working long hours. Family-school partnerships mean that teachers are an "extra pair of eyes" for busy, single parents. Teachers could monitor her daughter's academic progress and behavior. She states:

When you work two jobs, you don't have time to put your eyes on your daughter. ... Whatever she did in school I would know because the teacher would tell me. ... How does my daughter behave in school? Was she a happy child, is she happy? If looks like she is in trouble every day, then I know there is something, besides the B or C or grades. Something that I would not know, because I don't see how she behaves at school she could be happy child at home but when she goes to school she always has trouble. So, I know that she has social problems. Teachers can help with that.

Paula relies on teachers as an effective partner, because she wants her daughter to know there was another adult at school to support her. This suggests that teachers share the responsibility of helping busy parents like Paula to ensure that children are doing well at school. Perhaps the most effective way of making that happen is to keep an open channel of communication between parents and teachers. In doing this, Paula notes, "The children think ... 'I better not do bad in school because she is going to hear about it."”

Larry also believes that family-school partnerships refer to speaking with teachers about his children. However, he is more direct about what teachers can do. Larry notes:

If I go to school and ask how my kids are doing, I want a straight answer. I want them to tell me how I can help my kid to improve or what he needs to be done for him to improve something.

This appears to suggest that Larry is open to speaking with teachers about his child's progress at school, specifically when his son gets into trouble. But in that conversation, it would help Larry if he knows exactly what needs to happen to better support his child. This could mean telling Larry about where his son is struggling academically and/or behaviorally, thus focusing on very specific challenges, or providing more general recommendations about what his son should 
or should not do at home. Some recommendations may include reading more books to stimulate the brain or avoid watching too much television.

Sarah also views family-school partnerships as an opportunity for families and teachers to speak with each other. She states:

It's good if you have time with the teacher, to talk to them, get to know the teacher so the teacher can help ... tell you about how your kid is doing in this class. It's good if you have time to go there.

That appears to suggest that it is more effective for parents to have face-to-face conversations with teachers at school. Perhaps parents and teachers could dive deeper into discussions about "how your kid is doing in this class." Having the time to meet with teachers at school appears to be important to her, because parents and teachers could speak more directly about certain problems and how best to address them.

Charles also believes that family-school partnerships mean that families and schools communicate with each other. This partnership may have been important to Charles, because learning often takes place across settings. He notes:

Child's education starts first at home, then second at school. Kids start learning at home how to walk, talk, and behave while academics and skills are learned at school. Home and school work together by opening the communication between teachers, parents and students.

This suggests that family-school partnerships are more effective when parents, students, and teachers are constantly engaged in working together. Charles appears to suggest that teachers are responsible for academics at school, while parents taught and managed other issues including behavior at home. He also suggests that children learn across contexts, as learning may occur at home and school.

Charles also noted, "Teachers can encourage stronger partnership with families by educating them ... Educate parents mean to provide, equip them on how they can help their kids at home and openly let them know what the teachers are doing at school." In talking about teachers and families working together, Charles adds, "Teachers and parents must ... keep each other informed regarding the progress of our kids either at home or at school." Implicit in "equip them on how they can help their kids at home" may have been the idea that teachers ought to provide additional support to families, perhaps because teachers have a better understanding of what children need at school. With this statement, Charles may believe that some Cambodian parents need more support especially adults who do not have the capacity to speak English well enough to communicate with school partners. Therefore, teachers may need to provide extra attention to those families.

Steve also notes that some Cambodian parents may require additional support from teachers. Teachers should reach out to community members familiar with Cambodian families to access more information about the student. To that point, Steve mentions the following:

The best thing is for teachers to get to know the community or the community leader to find out information ... the teacher has to know ... I didn't get this information, and then find out through the community, "Okay, can you talk to this family because they have some 
kind of problem?" ... Or, if the teacher did not get a response from the parent they might contact with the community leader to know what's going on. ... And what can teachers do to help them. So when they get a response from the community they may know how they can contact the parent.

Steve appears to suggest that community members and community leaders are great resources for teachers to have, because "maybe teachers don't understand what's going on with the children" and therefore "the teacher has a big role to communicate and to contact with the community." He may attribute the need for teachers to reach out to community members, given his understanding that Cambodian families may lack an awareness of the American school system, in part because they are new to America. Thus, Steve states, "Cambodian families are new here and they don't know much about situations in this country." Because Cambodians "are new here," that implies that American teachers are still largely culturally unaware of Cambodian families at school and in the community.

Steve's comment about the community is interesting. But I wanted to know more, particularly how, and to what extent, the community could be the liaison between teachers and families. How feasible is it for teachers to reach out to community members? Though a good idea, it could add an additional layer of work onto an already seemingly hectic schedule for teachers. There also is the concern that some school partners may not have access to information about Cambodian community partners. When asked about what ought to happen if school partners had a difficult time reaching out to communities, which may prevent this partnership from being strengthened altogether, his response is:

Teacher has to know because each ethnic group in this country they have to have some kind of community. And they have to find out which ethnicity they are and so they have to find out. Especially the principal and counselor at school they know because they always have a list or something. Right now they have a lot of things they can search on and they will know. They can contact with each community leader and find out that way. Because a lot of resources are available not like before.

That response suggests that information pertaining to Cambodian community partners are available, and perhaps school partners having trouble accessing parents should reach out to community members and leaders. Community members may help teachers, parents, and students resolve problems at school. Perhaps the notion that parents should interact with parents through "the community" and "community leaders" reflects the organizational structure of rural villages in Cambodia, where the village leader (mei phum) represents the individual families in the village and arbitrates issues and needs. This dynamic may only apply to first generation Cambodian families, since second generation Cambodian Americans born and raised in the United States will have a very different cultural orientation than their parents.

The major theme here, "building family-school partnerships through communication," is based on commonalities distributed across all interviews. Patterns, on the other hand, represent the voices of at least three participants. To reiterate, there are two patterns under this theme.

Pattern A: Contacting parents about problems. This pattern refers to communication as a veritable method to share information about the child's progress, especially timely information for interventions to address academic and/or behavioral issues. Steve, David, Paula, Larry, Sarah, 
and Amy express the belief that families ought to communicate with school partners when children either demonstrate signs of or are currently addressing problems at school, and therefore families are expected to interact with teachers. Steve notes:

We have to have a good connection with the school teachers and find out what's the problem with your kids ... We have to check with the school to make sure ... if they have any behavior issue at school or anything like that we check, and what is the academic weakness for the kid, something that we can help, the teacher will know.

Paula, addressing her own daughter, states "Families and teachers have to talk to each other. I knew that my daughter is not good in something, because the teacher would write it down. And so I would talk to the teacher." Amy concurs by stating, "Talk to the counselors. Talk to the teachers, see how your child is progressing in school, if there's any problem," while Sarah notes, "It's good for teachers to let us know ... whatever students do wrong so we can correct the kid." David also notes:

For some students who have problems, I think that teachers can encourage work together with parents so students can know weak points strong points whatever the student needs and what they need to be corrected. Tell them the right path ... I think teachers play a strong role when the student has the problem.

These responses suggest that teachers ought to contact parents if students are having problems at school. Respondents may assume that there is no need to fix anything that is not broken. Thus, if children's grades and behavior are passing and satisfactory, respectively, then parents could assume that nothing is wrong. Children are doing what they are supposed to do. On some level, there is no need to bother teachers given the belief that teachers have busy and hectic schedules.

However, these beliefs may not be limited to Cambodian families. It may be a predominant trend across racial and ethnic groups across the United States. Thus, it appears that families in general, Cambodians and non-Cambodians alike, tend to be present and active at school when they need to reconcile a problem at school. In which case, families would need to address that concern, perhaps because they want to avoid any repercussions, legal or otherwise, that may ensue. One might assume that family members do not want to seem negligent.

Larry, for example, admits that his second-grade son gets into quite a bit of trouble, and therefore he spends significant time discussing disciplinary issues with his teachers. He notes:

The teacher will send me a letter saying my son is doing this bad. So I have to go and talk to the teacher ... But to be a teacher you have to love the kids. You have to focus on whoever has the problem.

However, Larry's concern is that teachers are not explicit enough on what needs to be done to take corrective action. He notes, "If they tell me what needs to be done, I'll do it." Larry, who dropped out of high school, has said in passing that he does not have the requisite knowledge or tools to advise his children because of his own limited experiences. Therefore, he may be relying quite heavily on teachers to help in that regard. 
Steve raises the issue about teachers being more explicit in supporting Cambodian families. He notes:

Teacher has to provide information to the parent. To let them know what's going on with your kid, either call or phone or send a letter and find out. That's a big thing that the teacher has to do with the parent.

This is particularly the case for Cambodian adults not proficient in reading, writing, or speaking English. Steve goes on to note:

For our Cambodian people ... most of them don't understand English. When the teacher call they don't know what they're talking about. When the letter comes they don't know what it is, they just throw away. And that's the main thing for our Cambodian people here. Because most of them, they non-educated and they don't know what's going on and how they can help the children.

In this instance, Steve is perhaps referring to "hard-to-reach" parents who may be less involved in their children's schooling experiences (e.g., throwing away letters from school because they cannot read English), perhaps because they do not know how, in part given their limited English proficiency skills. In that regard, Steve is suggesting that teachers ought to provide information to parents whose children may have been struggling academically and/or behaviorally. Therefore, one might argue that having the opportunity to communicate pertinent information between teachers and parents, but in a way that meets families' cultural and linguistic needs and abilities, would help to ensure that problems at school can be identified. On some level, it also suggests that for problems occurring at home, which could impact learning at school, an open channel of communication could help address certain issues with teachers.

Pattern B: Learning culture between families and teachers. This pattern refers to communication in terms of becoming more culturally aware of families. Respondents express concerns about the lack of cultural awareness among teachers at school, and how that could paint a negative picture of families. Deeper cultural awareness could prevent school partners from falsely assuming that children are having problems at home, often because of disciplinary practices. It also may prevent some Cambodian parents from getting into trouble with the law. In referring to a story about someone else's family, Steve notes:

There was a problem ... when the teacher saw the children, you know that usually when the children get sick Cambodian parents get the coin and rub ... Preang Krolah (i.e., Tiger Balm). And they rub the body to make it feel better. Teacher saw that and they called the police and asked, "What's going on?" ... That's why we have to teach teachers, they have to know about our Cambodian culture.

From this comment, Steve addresses a specific anecdote about how a traditional Cambodian medicinal practice (i.e., rubbing tiger balm on the body) is not only misconstrued by the teacher but comes with legal ramifications. This could imply that the teacher did not stop to ask for an explanation, either directly from parents or others perhaps more familiar with the Cambodian people. Instead, this teacher assumes perhaps prematurely that it was some form of 
child abuse. Perhaps the teacher could have avoided calling the police with a better understanding of the Cambodian culture, which might have transpired by openly communicating with parents about such cultural practices. Perhaps there is a power dynamic at play, in which the teacher (falsely) assumes that $\mathrm{s}(\mathrm{he})$ has more capacity to address this issue.

David also recalls a story about cultural awareness, and how one Cambodian family got into trouble with the law. He shares a story about someone else's family:

One of the family that had a problem the student coming home and the parent asked them to do the homework and the student don't want to do the homework and the parent said, "I'm going to spank you if you don't do that." And the student said, "If you spank me I'm going to call the police," and then the student said, "Okay, go ahead and spank me!" And the parent spank them and the child call the police.

David speaks to the act of disciplining children from the perspective of one Cambodian family. There appears to be differences between the so-called Americanized child and Cambodian parents in terms of the cultural norms of spanking. On that point, David further notes:

Between teachers and parents, it looks like a "cross-culture" because as a Cambodian family, we strictly discipline them. But in this country, if we discipline them sometimes it's against the law. ... But as Asians, we try to discipline them because we want them to go to the right path. But sometimes we do in the good heart but it turn out against the law. ... And I think that Americans should understand our culture.

Similar to Steve, David believes that Americans ought to learn about the Cambodian culture, which may include norms and practices, perhaps to avoid misjudging Cambodian parents who, in this case, may find it particularly necessary to spank their child in order to help him stay on "the right path."

David also notes, "In our Cambodian culture the parent has the right to discipline the children as long as we not hurt them so bad," which suggests that David is not supporting extreme physical abuse, but rather spanking as a necessary means to discipline children. He further notes, "Sometimes as a child we got to discipline them and tell them the right way. And sometimes they are hardhead and need to be disciplined and over here in this culture that is against the law." From David's comment, it appears that he is asking Americans, and perhaps American teachers, to better understand how Cambodian parents discipline children, perhaps to avoid assuming that children are abused at home. Having conversations with Cambodian parents about these concerns may enable teachers to learn why parents believe corporal punishment is effective. In having these conversations, parents may share that spanking their children is one way to ensure that young people do not fall through the cracks, whether at school or in society. Conversely, parents may also learn about the long-term emotional and psychological distress corporal punishment could have on the child.

Larry, who also shares David's observation regarding corporal punishment, believes that spanking sometimes is necessary in disciplining children. In his experience, he notes, "Back then in the homeland, the teacher, when you do something wrong, they spank you, which my dad was okay with that. I wish it would be the same way right now." Larry further notes, "Right now, the kids are being bad, all the way from home to school. They don't respect teachers." Larry seems to express his concerns regarding the level of "disrespect" shown by young people today towards 
adults. Because of that lack of respect, sometimes young people should be spanked. Larry appears to raise this concern because it reflects how he disciplines his son when he gets into trouble. Larry may believe that spanking is more effective than using time-out or grounding.

Spanking is not a Cambodian specific cultural phenomenon. Other countries and cultures, including those practiced in the United States, utilize spanking as a method to discipline children. However, it is interesting for respondents to view teachers in Cambodia similar to parents. In Cambodia, for example, parents often give teachers full disciplinary rights to spank their children without consequences onto them. For example, David discusses how this cultural norm of spanking children is not only condoned by parents but a shared practice between families and teachers in Cambodia. "Even though they go to school, in Cambodia the teacher can discipline them to some extent but not to hurt our children. Over here in America when teachers spank the student it looks like it's against the law." Again, David suggests that Cambodian teachers have permission to use corporal punishment if children are misbehaving, so long as teachers know their limits and "not hurt them so bad." David further states, "In our culture the teachers looks like the parents, next to the parent is the teacher." This might suggest that teachers are an extension of parents at school and disciplining children is a shared responsibility.

Regarding "it's against the law," David seems to refer to those states in the United States that have banned corporal punishment, whether at home or at school-thus making it illegal. Perhaps he is referring to school corporal punishment only being legal under domestic law in 20 states of the United States (see Stephey, 2009). Teachers residing outside of those states, functioning under their respective laws, may be held legally liable for spanking their studentsthough parents like Larry may grant them permission to spank his children.

Thus, learning about cultural differences-whether traditional medicinal practices or spanking as a seemingly acceptable form of disciplinary practice-may be an effective way for teachers and families to communicate with each other. Communicating in this manner could help adults to better understand one another.

\section{Discussion}

\section{Strengthen Partnerships Through Cultural Awareness}

Findings suggest that partners should engage in a bilateral process of communicating, while honoring the cultural awareness of Cambodian American families. For example, Steve notes, "We have to teach teachers, they have to know about our Cambodian culture." David mentions, "Between teachers and parents, it looks like a 'cross-culture' because as a Cambodian family, we strictly discipline them ... Americans should understand our culture." Steve also notes, "Cambodians have to learn from Americans, you know the culture. You cannot beat the children; you cannot do anything bad onto the children."

Findings indicate that some families continue to endorse strict, or conservative, practices in disciplining children. The use of corporal punishment appears to be tolerated by Larry and David, though Steve speaks against it, and supporting corporal punishment may in part be a result of their own strict upbringing. Larry, for example, gives permission to teachers to spank his children, if the need to do so is justified. Those practices, however, typically are not accepted or practiced by mainstream America. David reminds us that, "We strictly discipline them. But in this country, if we discipline them sometimes it's against the law." 
Existing research does not speak to learning about corporal punishment as a way to strengthen family-school partnerships, especially for Cambodian Americans. However, Tran, Lee, and Khoi (1996) examine stressful life events in a sample of 70 SEAAs, specifically among Cambodian, Hmong, and Vietnamese adolescents. Their study finds that Cambodians rank strict discipline in social life by parents as the most stressful. Hmong and Vietnamese adolescents report doing house chores and academic pressure to do well, respectively, as the most stressful. While strict discipline does not necessarily mean corporal punishment, one might argue that mixed cultural signals could be transmitted to Cambodian adolescents in Tran and colleagues' study. That is, Cambodian adolescents might experience strict discipline in social life at home, while at school they interact with American peers who experience more social freedom. These cultural signals may be confusing for young Cambodians, and that may create problems at home and school. In interviewing a small sample of Hmong American students, Thao (2003) examines how, and to what extent, home and school factors interact with each other. His study finds that differences in culture (or, what Thao refers to as "cultural clash") at school and at home undermine family-school partnerships. Pho's (2007) research also finds disconnects between cultural expectations at home and school. Quoting one Vietnamese student, Pho notes, "What we learned in school sometimes was different from what we were taught at home ... While our teachers wanted us to talk in class and to be independent, our parents wanted us to be quiet and respect older people" (2007, p. 70). The absence of a clear cultural understanding can complicate the learning experiences for young Cambodians. These cultural miscues may have prompted that young man in David's interview, for example, to threaten his parents with legal enforcement, if they spanked him, when their intentions may have been good.

Other studies indicate that first-generation immigrant parents often administer corporal punishment as a form of disciplining their children, though some American courts deem such practices too excessive (Renteln, 2010). Some alternative methods to "spanking" include praising and rewarding good behavior, in addition to talking to children about the natural and logical consequences of misbehavior. Parents may also speak with culturally sensitive professionals including their pediatricians about the deleterious effects of corporal punishment and the advantages of less physical strategies in disciplining children (American Academy of Pediatrics, 1998).

Findings from this study also build on studies that address cultural barriers for SEAAs. For example, the National Coalition of Advocates for Students (NCAS) (2000) study, Capacity Building for SEAA family-school partnerships, point out, "Language and cultural barriers exclude many SEAA parents from learning about school policies and ways they can participate in homeschool activities" (2000, p. 7). The inability to speak English well, or at all, could prevent Cambodian families from supporting children with homework assignments. Non-English speaking parents may not know how to access information and resources to help young people at school. One example could be the idea or process of Advanced Placement (AP) or SAT exams for college and making sure that children submit applications on time. Not being able to speak, read, or write English could prevent parents from finding appropriate SAT prep courses or after-school and summer programs often afforded to their more affluent peers.

While at face value this might suggest that Cambodian parents "play into" the essentialization theory of achievement, which often consumes discussions on Asian Americans in general, thus reinforcing oppressive frames including the model minority myth, it also is important to pontificate factors similar to "SAT prep courses" particularly in thinking about how more affluent peers are able to access "social and cultural capital" (Bourdieu, 1986) once they have been 
admitted to the most elite educational and occupational institutions - in which a necessary first step is "playing into the system" of excelling academically in a country that continues to place restrictive barriers to said institutions based on test scores. Complicate that point to the (very real) fact that Cambodians (and, indeed, other SEAAs) are still equated (wrongly) to middle- and upperclass Asian Americans in college admissions decisions in which they do not and cannot benefit from affirmative action despite their low-income background (Hartlep \& Lowinger, 2014; Park \& Liu, 2014), one might argue that until low-income SEAAs in general are better understood and represented fairly - by admissions officers, for example - they will need to master the art of excelling in all areas that lead to access and opportunity. Again, this argument does not subscribe to (academic) essentialization but rather addresses a pragmatic (racist American) situation which explicitly acknowledges institutional barriers, especially for those students and parents who believe unequivocally in higher education as a way out of poverty. This idea, of course, does not and should not apply to all family values.

Lastly, the assumption that cultural barriers are challenges for ethnic Cambodian parents is supported by Aung and Yu (2007). They find that Cambodian parents often lack formal education and do not have the necessary skills to help their children navigate schools, in part because they "do not understand how to maneuver within the American education system" (2007, p. 93). The authors further note that "because of these cultural barriers, as well as linguistic and educational challenges, many Cambodian parents ... are unable to advocate effectively for their children in the public education system" (p. 94). Thus, having the capacity to "advocate effectively" is important because one might argue that families could advocate more effectively for the child than any other adult or person. And though teachers can be strong advocates, there is reason to believe that they often cannot do it effectively for every child. Cultural understanding may have been addressed by respondents, as they recognized the on-going challenges it presents to Cambodian families, particularly in the context of working with schools and raising their children in a new country.

\section{Conclusion and Future Research}

It is not the intention of this study to essentialize Cambodian Americans in the context of academic achievement and excellence. However, it would be naïve to suggest that one could divorce culture from structure (Noguera, 2008). That the present study examines a social phenomenon in the context of public education, one must necessarily invoke discussions on achievement - though recognizing it is only one measurable outcome. It is equally important to note that conversations apropos educational attainment and achievement would not be complete without situating them in the broader cultural and structural context of racial oppression, given the fact that Asian Americans, and particularly marginalized subgroups similar to Cambodian Americans, have never benefitted from hierarchies of power - not to mention the dominant class (Tchen \& Yeats, 2014). Therefore, one might argue that to better understand the role of culture in strengthening familyschool partnerships, we must concurrently understand the structural barriers that hinder young SEAAs and their families from exceling in the public educational system and life in general. Examples of structural barriers include multigenerational poverty and institutional oppression in education and society.

For example, Keo (2010) reviews the literature on family-school partnerships in public

education and finds that an overwhelmingly large majority of the literature is written by non-SEAA 
researchers. Most scholars make suggestions on strengthening partnerships "for America writ large" absent of a clear cultural component that fully honors the voices of Cambodian American families. These scholars also ignore the bigger systemic forces that may impact the way in which partnerships are formed in public education and perhaps more importantly who holds positions of power in these dynamics.

In that regard, future researchers should further explore the notion of cultural competency in the context of race, ethnicity, and education. Gloria Ladson-Billing, a leading critical race scholar in education aptly notes: "Race is a reliable predictor of school dropout, suspension, expulsion, assignment to special education, and the likelihood of being taught by unqualified and under-qualified teachers" (2011, p. 1455). Researchers might be interested in exploring how K12 curricula and lessons can be improved and strengthened to incorporate cultural content that speaks to the historical, political, social, and economic experiences of Cambodian families before and after entering the United States. Did they enter the United States seeking economic prosperity or were they politically and militarily forced out of the homeland? What levels of education and workforce experience did they attain prior to entering the United States? How can these fluid and dynamic lived experiences serve as a resource in the process of curricular decolonization (Goodwin, 2010), which asserts that extant curricular contents often conceal facts that reveal an egregious American history, which includes failed United States foreign policies that contributed to the political instability leading to the 1975-1979 Cambodian genocide in which an estimated two million people were killed mercilessly (Shawcross, 1987)?

In connecting research to practice and policy outcomes, researchers should think about how to incorporate cultural competency lessons into teacher preparation programs at the beginning of the school year, especially for new teachers. Researchers might also want to explore how veteran teachers can have professional development opportunities to learn or strengthen cultural competency, while also serving as mentors for new teachers. Researchers could also explore culturally appropriate programs to help families learn about American cultural norms and values. These programs may help Cambodian families better navigate school systems that were originally designed to assimilate immigrants to the broader hegemonic cultural values of America, not to ensure that every child regardless of background succeeds. Overcoming such cultural and structural barriers may help to strengthen access and opportunities for young people especially from marginalized Asian American families and communities.

\section{References}

American Academy of Pediatrics. (1998). Guidance for effective discipline. Pediatrics, 101(4). 723-728.

Aung, K. M., \& Yu, N. (2007). Does the system work for Cambodian American students? The educational experiences and demographics of Cambodians in Lowell, Massachusetts. In T. Pho, J. N. Gerson, \& S. R. Cowan (Eds.), Southeast Asian refugees and immigrants in the Mill City (pp. 88-111). Burlington, VT: University of Vermont Press.

Bourdieu, P. (1986). The forms of capital. In J. Richardson (Ed.), Handbook of theory and research for the sociology of education (pp. 241-258). New York, NY: Greenwood Press. 
Delgado, R., \& Stefancic, J. (2012). Critical race theory: An introduction. New York, NY: New York University Press.

Epstein, J. L. (1995). School/family/community partnerships: For the children we share. Phi Delta Kappan, 76, 701-712.

Epstein, J. L. (2001a). Building bridges of home, family, and community: The importance of design. Journal of Education for Students Placed at Risk, 6(1/2), 161-168.

Epstein, J. L. (2001b). School, family, and community partnerships: Preparing educators and improving schools. Boulder, CO: Westview.

Epstein, J. L. (2008). Improving family and community involvement in secondary schools. Education Digest, 73(6), 9-12.

Epstein, J. L., \& Salinas, K. C. (2004). Partnering with families and communities. Educational Leadership, 61(8), 12-17.

Glaser, B. G., \& Strauss, A. L. (1967). The discovery of grounded theory: Strategies for qualitative research. New Brunswick, NJ: Aldine Transaction.

Goodwin, A. L. (2010). Curriculum as colonizer: Asian American education in the current context. Teachers College Record, 112(12), 3102-3138.

Hartlep, N. D., \& Lowinger, R. J. (2014). An exploratory study of undergraduates' attitudes toward affirmative action policies for Asian Americans in college. Equity \& Excellence in Education, 47(3), 370-384.

Henderson, A. T., \& Mapp, K. L. (2002). A new wave of evidence: The impact of school, family, and community connections on student achievement. Austin, TX: Southwest Educational Development Laboratory.

Henderson, A. T., Mapp, K. L., Johnson, V. R., \& Davies, D. (2007). Beyond the bake sale: The essential guide to family-school partnerships. New York, NY: The New Press.

Kao, G., \& Tienda, M. (1995). Optimism and achievement: The educational performance of immigrant youth. Social Science Quarterly, 76(1), 1-19.

Keo, P. T. (2010). Cambodian family-school partnerships: Toward an evolving theory, Journal of Southeast Asian American Education \& Advancement, 5(1), 1-28.

Kiang, P. N. (2004a). Checking SEAA realities in Pan-Asian American agendas. AAPI Nexus: Policy, Practice and Community, 2(1), 48-76.

Kiang, P. N. (2004b). Linking strategies and interventions in Asian American studies to K-12 classrooms and teacher preparation. International Journal of Qualitative Studies in Education, 17(2), 199-225.

Ladson-Billings, G. (2011). Race to the top again: Comments on the genealogy of critical race theory. Connecticut Law Review, 43(5), 1439-1458.

Lee, S. (2006). Additional complexities: Social class, ethnicity, generation, and gender in Asian American student experiences. Race Ethnicity and Education, 9(1), 17-28.

Lopez, G. (2001). On whose terms? Understanding involvement through the eyes of migrant parents. Paper presented at the annual meeting of the American Educational Research Association, Seattle, WA.

Nakkula, M. J., \& Pineda, C. G. (2005). Students at-risk. In S. J. Farenga, B. A. Joyce \& D. Ness (Eds.), Encyclopedia on education and human development (pp. 389-428). Armonk, NY: M.E. Sharpe, Inc.

National Coalition of Advocates for Students (NCAS). (2000). Capacity building for SEAA familyschool partnerships. Cambridge, MA: Harvard Family Research Project. 
National Commission on Asian American and Pacific Islander Research in Education (CARE). (2010). Federal higher education policy priorities and the Asian American and Pacific Islander Community. Retrieved August 1, 2014, from http://apiasf.org/CAREreport/2010_CARE_report.pdf

National Commission on Asian American and Pacific Islander Research in Education (CARE). (2011). The relevance of Asian Americans \& Pacific Islanders in the college completion agenda, 1-32. New York, NY: New York University Press.

Ngo, B., \& Lee, S. J. (2007). Complicating the image of model minority success: A review of Southeast Asian American education. Review of Educational Research, 77(4), 415-453.

Noguera, P. (2008). The trouble with black boys: and other reflections on race, equity, and the future of public education. San Francisco, CA: Jossey-Bass.

Ong, A. (1999). Cultural citizenship as subject making: Immigrants negotiate racial and cultural boundaries in the United States. In R. Torres, L. Miron, \& J. Inda (Eds.), Race, identity, and citizenship: A reader (pp. 262-293). Berkeley, CA: University of California Press.

Park, J. J., \& Liu, A. (2014). Interest convergence or divergence? A critical race analysis of Asian Americans, meritocracy, and critical mass in the affirmative action debate. Journal of Higher Education, 85(1), 36-64.

Pho, T. (2007). Family education and academic performance among SEAA students. In T. Pho, J. N. Gerson, \& S. R. Cowan (Eds.), Southeast Asian refugees and immigrants in the Mill City (pp. 69- 87). Burlington, VT: University of Vermont Press.

Portes, A., \& Rumbaut, R. G. (2001). Legacies: The story of the immigrant second generation. Berkeley and Los Angeles, CA: The University of California Press.

Renteln, A.D. (2010). Corporal punishment and the cultural defense. Law \& Contemporary Problems, 73(2), 253-279.

Sandoval, N. I. (2007). Bridging generations: American Indian family perceptions of home/school partnerships (Unpublished doctoral dissertation). University of California, Santa Barbara.

Shawcross, W. (1987). Sideshow: Kissenger, Nixon and the destruction of Cambodia. New York, NY: Simon and Schuster.

Sheldon, S. B., \& Epstein, J. L. (2002). Improving student behavior and school discipline with family and community involvement. Education \& Urban Society, 35(1), 4-21.

Silva, S. S. (2001). Cultural differences and attitudes towards parental involvement: A case study of preschool parents (Unpublished doctoral dissertation). Southern Illinois University, Carbondale.

Stephey, M.J., “Corporal Punishment in U.S. Schools,” Time, New York, 12 August 2009. Retrieved from: http://www.time.com/time/nation/article/0,8599,1915820,00.html.

Stevenson, D. L., \& Baker, D. P. (1987). The family-school relation and the child's school performance. Child Development, 58(5), 1348-1357.

Suarez-Orozco, C., \& Suarez-Orozco, M. M. (2001). Children of immigration. Cambridge, MA: Harvard University Press.

Tchen, J. K.W., \& Yeats, D. (2014). Yellow peril! An archive of anti-Asian fear. New York, NY: Verso.

Thao, Y. J. (2003). Empowering Mong students: Home and school factors. Urban Review, 35(1), $18-42$.

Tran, Q. D., Lee, S., \& Khoi, S. (1996). Ethnic and gender differences in parental expectations and life stress. Child \& Adolescent Social Work Journal, 13(6), 515-526. 
Uy, P. S. (2007). Response K-12 education: How the American community survey informs our understanding of the Southeast Asian American community: One teacher's perspective. Journal of Southeast Asian American Education \& Advancement, 3, 44-48.

Wu, F. H. (2003). Yellow: Race in America beyond Black and White. New York, NY: Basic Books.

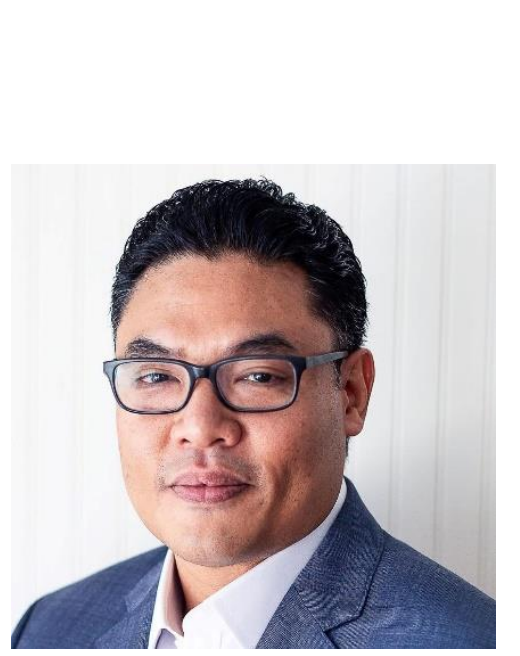

\begin{abstract}
About the Author
Peter T. Keo, is a global scholar and researcher. His work addresses issues ranging from human rights and democracy in wartorn Southeast Asia to advancing equitable outcomes for vulnerable populations in PreK-12 American public schools. In the U.S., Dr. Keo conducts research and evaluates the effectiveness of major federal and state educational policies to support chronically lowperforming urban and rural districts and schools. He also conducts research on boys and men of color and the impact of Asian American stereotyping on research and public policy outcomes. Globally, he contributed to the rebuilding of higher educational institutions in post-genocidal Cambodia, which included
\end{abstract} supporting the former Minster of Education in redrafting the Cambodian Educational Law.

Dr. Keo is currently Visiting Scholar in the Human Development \& Quantitative Methods Division in the University of Pennsylvania, Graduate School of Education. He holds a joint Visiting Scholar appointment at Dr. Pedro Noguera's Center for the Transformation of Schools at UCLA. Keo was Postdoctoral Research Fellow at the University of Pennsylvania and Principal Investigator (PI) of two large national studies. He has served in senior leadership roles working in higher education, nonprofit organizations, and think tanks. His work has appeared in leading research journals and book chapters in addition to editorials including Education Week, Teachers College Record, The Diplomat, and Pacific Forum CSIS. Dr. Keo received his doctorate in education from Columbia University, in addition to master's degrees from Harvard University and the University of Chicago. He is certified in "Evaluating Social Programs - Using Randomized Controlled Trials" from the Massachusetts Institute of Technology (MIT), through the Poverty Action Lab. His parents are Cambodian refugees. He is a first-generation high school graduate. 


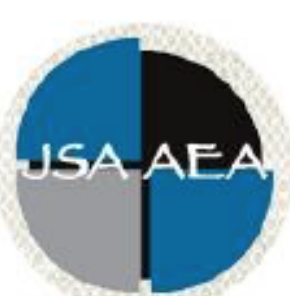

Vol.14 Iss.1 (2019)

\title{
Journal of Southeast Asian American Education and Advancement
}

\author{
www.JSAAEA.org
}

\section{Editor}

Dr. Wayne E. Wright

Purdue University

Associate Editors

Dr. Chhany Sak-Humphry

University of Hawaii at Manoa

Dr. Phitsamay Sychitkokhong Uy

University of Massachusetts, Lowell

\author{
Book Review Editor \\ Dr. Vichet Chhuon \\ University of Minnesota \\ Creative Works Editor \\ Bryan Thao Worra \\ Lao Assistance Center \\ Journal Manager \\ Fang Gao \\ Purdue University
}

Editorial Review Board

Dr. Steve Arounsack

California State University, Stanislaus

Dr. Sovicheth Boun

Salem State University

Dr. Virak Chan

Purdue University

Dr. Loan Dao

University of Massachusetts Boston
Dr. Carl L. Bankston III

Tulane University

Dr. Phala Chea

Lowell Public Schools

Dr. George Chigas

University of Massachusetts, Lowell

Dr. Hien Duc Do

San Jose State University 


\author{
Dr. Changming Duan \\ University of Missouri-Kansas City \\ Dr. Sothy Eng \\ Lehigh University \\ Dr. Vincent K. Her \\ University of Wisconsin, Eau Claire \\ Dr. Peter Nien-Chu Kiang \\ University of Massachusetts, Boston \\ Dr. Kevin K. Kumashiro \\ University of Illinois, Chicago \\ Dr. Ha Lam \\ Independent Scholar \\ Dr. Jonathan H. X. Lee \\ San Francisco State University \\ Dr. Monirith Ly \\ Royal University of Phnom Penh \\ Dr. Bic Ngo \\ University of Minnesota \\ Dr. Leakhena Nou \\ California State University, Long Beach \\ Dr. Mark Pfeifer \\ SUNY Institute of Technology \\ Dr. Loan T. Phan \\ University of New Hampshire \\ Dr. Karen Quintiliani \\ California State University, Long Beach \\ Dr. Angela Reyes \\ Hunter College \\ The City University of New York \\ Dr. Fay Shin \\ California State University, Long Beach \\ Dr. Christine Su \\ College of San Mateo \\ Dr. Alisia Tran \\ Arizona State University \\ Dr. Khatharya Um \\ University of California, Berkeley \\ Dr. Kim Tran \\ University of California, Los Angeles, \\ Glendale Community College \\ Dr. Molly Wiebie \\ The University of Texas at Austin
}

Dr. Sophal Ear

Occidental College

Dr. Jeremy Hein

University of Wisconsin, Eau Claire

Dr. Nancy H. Hornberger

University of Pennsylvania

Dr. Peter Tan Keo

New York University

Dr. Yvonne Kwan

San Jose State University

Dr. Ravy Lao

California State University, Los Angeles

Dr. Stacey Lee

University of Wisconsin, Madison

Dr. Sue Needham

California State University, Dominguez Hills

Dr. Max Niedzwiecki

Daylight Consulting Group

Dr. Clara Park

California State University, Northridge

Dr. Giang Pham

University of Massachusetts Amherst

Dr. Malaphone Phommasa

University of Clifornia Santa Barbara

Dr. Kalyani Rai

University of Wisconsin-Milwaukee

Dr. Cathy J. Schlund-Vials

University of Connecticut, Storrs

Dr. Nancy J. Smith-Hefner

Boston University

Dr. Yer J. Thao

Portland State University

Dr. Monica M. Trieu

Purdue University

Dr. Silvy Un

Saint Paul Public Schools

Dr. Linda Trinh Vo

University of California, Irvine

Dr. Yang Sao Xiong

The University of Wisconsin-Madison

Dr. Zha Blong Xiong

University of Minnesota 


\section{Doctoral Student Editorial Review Board}

\author{
Linh Dang \\ University of Rochester \\ My-Lan Huynh \\ California State University East Bay \\ Hoa Nha Nguyen \\ Boston College \\ Thien-Huong Ninh \\ University of Southern California \\ Krissyvan Truong \\ Claremont Graduate University \\ Melissa Vang \\ San Diego State University \\ Claremont Graduate University
}

\author{
Annie BichLoan Duong \\ San Joaquin County Office of Education \\ Dung Minh Mao \\ University of Minnesota \\ Khoi Nguyen \\ George Mason University \\ Linda Marie Pheng \\ University of Wisconsin-Madison \\ Mai Vang \\ University of Massachusetts Boston \\ Soua Xiong \\ San Diego State University \\ Claremont Graduate University
}

